\title{
Financing Strategies of New Technology-Based Firms: A Comparison of Women-and Men-Owned Firms
}

\author{
Alicia M. Robb', Susan Coleman²
}

\begin{abstract}
In this article we used data from the Kauffman Firm Survey to compare the financing strategies of women-and men-owned new technology-based firms. Our findings reveal that women raised dramatically less financial capital than men in the startup year and in the subsequent four years of operation. We also found that women used a significantly higher level of external debt and a significantly lower level of external equity during the startup year. Although our findings do not allow us to definitively rule out the possibility of discrimination, particularly in the market for external equity, our results indicate that women may have different motivations and expectations for their firms. These, in turn, may determine some of their financing choices.
\end{abstract}

Keywords: new technology-based firms; women-owned firm; financing strategies.

\footnotetext{
' Ewing Marion Kauffman Foundation. 480I Rockhill Road. Kansas City, MO 64I I0. Phone: 415-259-9009. Email: arobb@kauffman.org

${ }^{2}$ Barney School of Business. University of Hartford. 200 Bloomfield Avenue. West Hartford, Connecticut 06I I 7. Phone: 860-768-4690. Email: scoleman@hartford.edu
} 


\section{Introduction}

New technology-based firms have been and will continue to be important contributors to both the U.S. and global economies. For the past two decades, they have been a major source of innovation, business development and growth, and new jobs. Securing funding for new technology-based firms is particularly problematic, however, regardless of whether they are owned by women or men. Many such firms are built upon intellectual capital rather than on physical assets, so it is difficult to determine the value and prospects of the firm. The problem of asymmetric or incomplete information is especially acute (Brierley, 200I), often resulting in a shortage of capital or capital that can only be obtained under unfavorable terms and conditions.

Prior research attests to the financing difficulties faced by technology-based entrepreneurs, particularly in the early stages of the firm. Many such firms rely heavily on the personal financial resources of the entrepreneur, because the firm lacks assets that can be used as collateral for loans, and its products and services are new and, as yet, untested (Moore, 1994; Westhead and Storey, 1997; Bollingtoft et al., 2003; Guidici and Paleari, 2000). As the business matures, the problem of information asymmetry becomes less severe, and firms able to survive to that point have opportunities to draw upon a broader range of financing sources (Colombo and Grilli, 2007; Audretsch and Lehmann, 2004; Freear and Wetzel, 1990; Manigart and Struyf, 1997). Several researchers refer to this as the "life cycle" of financing whereby different sources of funding become substitutes for each other (Bozkaya and De La Potterie, 2008). Thus, personal sources of financing are eventually replaced by SBIR grants or bank financing which are in turn replaced by angel and venture capital funding (Brierley, 200I; Lerner, 1999; Audretsch, 2002).

The shortage of capital and difficulties in securing capital are often even more visible in firms owned by women (Orser et al., 2000; Coleman, 2002; Marlow and Patton, 2005). Women-owned firms tend to be smaller and have traditionally concentrated in low-growth retail and service lines of business rather than in technology-based businesses (Rosa et al., 1996; Du Rietz and Henrekson, 2000). Due to their highly competitive nature, retail and service firms have a greater risk of failure (Robb, 2002;
Fairlie and Robb, 2009; Watson, 2003) combined with limited prospects for growth and profitability (Menzies et al., 2004; Sabarwal and Terrell, 2008). Taken together, these characteristics make women-owned firms less attractive to external providers of capital. Thus, women entrepreneurs tend to have less experience with and access to external sources of debt and equity in general. More recently, however, researchers associated with the Diana Project (Brush et al., 200I) have begun to attack the "myth" that women do not want high-growth businesses. Brush et al. (200I) contend that a new generation of women entrepreneurs is willing to "go boldly where no one has gone before" by starting firms in the fields of technology and bioscience, where there are opportunities for significant growth and profits. Rapid growth brings with it the requirement for larger amounts of capital, and, in particular, larger amounts of external capital.

To date there have been relatively few studies on the financing experience of women technology-based entrepreneurs. Those that are available reveal that they face significant barriers and challenges. The authors of the Diana Project (Brush et al., 200I) found that women entrepreneurs in growth-oriented ventures received only 4.8 percent of venture capital funding for the period of 1953 through 1998. They observed that the venture capital industry continues to be a male-dominated and closed network that most women do not have access to. Diana Project researchers (Brush et al., 2004; Gatewood et al., 2009) found that there were relatively few women with sufficient wealth and experience to allow them to serve as investors capable of promoting the cause of new growth-oriented women entrepreneurs. Consistent with the findings of the Diana Project, several studies have noted that women entrepreneurs typically do not have the type of senior management decision-making experience that is required by external equity investors (Tai and Sims, 2005; Cross and Lineham, 2006; Hollowell et al., 2006; Mayer, 2008). Women employed in technology-based firms tend to occupy supervisory rather than managerial ranks, and they express frustration with being closed out of important networks and decisions. This suggests that women owners of technology-based firms face a triple bind. They do not have sufficient personal financial capital to grow their firms, they do not have the human capital (experience) to attract external capital, and they do not have the social 
capital (networks) to provide links with needed sources of funding.

As noted above, the major shortcoming of research on the financing strategies of women technology-based entrepreneurs is that there is so little of it. At present, we know very little about how new, women technologybased entrepreneurs finance their firms. This article seeks to address that gap by comparing the financing strategies of women- and men-owned new technology-based firms using data from the Kauffman Firm Survey. In particular, we will determine if women entrepreneurs use the same financing sources and amounts as men. If this is not the case, it may suggest either differences in financial strategy or barriers that impede access to capital for women attempting to launch technology-based firms.

The format of this article is as follows. The introduction will be followed by a section on methodology which includes information on data, definitions, and the specification of the multivariate model. Next, we present and analyze our descriptive and multivariate findings. The paper concludes with a section on conclusions and implications for further research.

\section{Methodology}

\section{I Data and Definitions}

The Kauffman Firm Survey (KFS) is a longitudinal survey of new businesses in the United States. The sampling frame for the KFS is based on the Dun and Bradstreet (D\&B) database. This survey collected information on 4,928 firms that began operations in 2004 and surveys them annually. This cohort is the first large national sample of firm startups that will be tracked over time. These data contain detailed information on both the firm and up to ten business owners per firm. In addition to the 2004 baseline year data, there are four years of follow-up data (2005-2008) now available. Three additional years are planned. Detailed information on the firm includes industry, physical location, employment, profits, intellectual property, and financial capital (equity and debt) used at startup and over time. Information on up to 10 owners includes age, gender, race, ethnicity, education, work experience, and previous startup experience. The detail provided by these data allows us to compare the financial strategies and the use of both debt and equity for new firms. For more information about the KFS survey design and methodology, please see Robb et al. (2009). A public use dataset is available for download from the Kauffman Foundation's website and a more detailed confidential dataset is available to researchers through a data enclave provided by the National Opinion Research Center (NORC). For more details about how to access these data, please see www.kauffman.org/kfs.

We define technology-based firms in the following manner. Firms were designated as technology-based by a definition, which is based on Chapple et al. (2004), identifying a set of occupations that are science and engineering intensive as well as industries whose shares of employment in those occupations were three times the national average. For purposes of this research, we used this refined list of industries at the six-digit NAICS level provided by the Carnegie Mellon University Center for Economic Development (CED). These types of firms are often referred to as "technology employers". Firms were also designated as technology-based based on a definition that uses industry data from the NSF's Survey of Industrial Research and Development and classified firms as primary technology generators if they exceeded the U.S. average for both research and development expenditures per employee and for the proportion of full-time-equivalent R\&D scientists and engineers in the industry workforce (Paytas and Berglund, 2004). These types of firms are referred to as "technology generators". There is quite a bit of overlap between firms defined as "technology employers" and "technology generators". We refer to technology-based firms as firms that fit either (or both) of these classifications. For a detailed list of NAICS codes that make up this technology-based firm definition, please see Appendix A.

A subset of the confidential Kauffman Firm Survey dataset was used for this research-those firms that had data for all five survey years and those that had been verified as going out of business over the 2004-2008 period. There were more than 500 technology-based firms in the Kauffman Firm Survey baseline year.

\subsection{The Multivariate Model}

We explore gender differences in financing patterns of new technology-based firms by regressing initial capital structure ratios on owner and firm characteristics. The OLS regression model is in the following form:

ISSN: 07I 8-2724. (http://www.jotmi.org)

Journal of Technology Management \& Innovation () Universidad Alberto Hurtado, Facultad de Economía y Negocios 
Financing Category/Total Financial Capital $=\alpha+\gamma \mathrm{F}_{\mathrm{i}}+\beta \mathrm{K}_{\mathrm{i}}$ $+\varepsilon_{\mathrm{i}}$,

where $F$ is a vector of owner characteristics and $K$ is a vector of firm characteristics.

The dependent variable is a financial ratio representing a particular source of financing divided by total startup financial capital. The types of financing investigated using four different financial ratios as dependent variables were as follows: I) owner financing (sum of owner debt and owner equity)/total financial capital, 2) insider financing (sum of insider debt and insider equity)/total financial capital, 3) outsider debt/total financial capital, and 4) outsider equity/total financial capital.

As noted above, independent variables include measures of firm and owner characteristics in light of the fact that prior research has revealed that the financial strategies of small firms are driven by both. In our model, primary owner characteristics include measures of human capital (education, previous industry experience, and average hours worked), as well as gender. Previous research has revealed that owners with higher levels of education are more likely to secure external equity financing (Carter et al., 2003; Menzies et al., 2004). Similarly, measures of prior experience including previous startup experience and previous industry experience have been predictors of firm survival and success (Cooper et al., 1994). These various human capital attributes may serve as important signals regarding the prospects of the firm to external investors, thereby alleviating some of the problems associated with asymmetric information. The variable "hours worked" was included because it seems reasonable to assume that owners who devote more time to their firms will experience greater success not only in terms of firm performance but in their efforts to secure capital as well (Coleman and Robb, 2009). Finally, the gender variable allows us to capture key differences in financing strategy between women- and men-owned new technology-based firms, after controlling for other factors.

Firm characteristics include measures of organizational status (multi-owner), intellectual property (patents, trademarks, and copyrights), firm credit quality, and product and service offerings by the firm. From a financing perspective, multiple owners should be an advantage for the firm, because they are in a position to invest larger amounts of personal capital (Coleman and Robb, 2009). Further, multiple owners may have a broader network of contacts that will also allow them to be more effective in securing external sources of capital. Intellectual capital is an important form of competitive advantage for technology-based firms, because it serves as a signal to external investors (Coleman and Robb, 2009). Similarly, intellectual capital in the form of patents, copyrights, and trademarks can protect the firm from competition and allow it to build market share and revenues during the early stages of its development. Measures of firm credit quality (high credit score, medium credit score) could serve as a predictor of the firm's capacity to raise additional debt capital, compared with firms having low credit scores. In particular, those firms that prefer to use external debt rather than external equity could increase their access and lower their costs by maintaining a favorable credit rating (Coleman and Robb, 2009). As with intellectual property, the presence of tangible products can help to alleviate the problem of asymmetric information for potential investors. Thus, we would expect product and/or product with service offerings to improve a firm's chance of raising external capital, compared with firms that offer just services.

\section{Findings and Analysis}

\section{I Descriptive Statistics}

\section{A. Characteristics of Technology-Based Firms by Gender at Startup (2004) and in the Fifth Year (2008)}

Table I provides descriptive statistics, by gender, for technology-based entrepreneurs included in the Kauffman Firm Survey. It reveals some striking differences between women and men who launched firms during the startup year, which persist through the five years of observation. We compare all technologybased firms by primary owner gender in the startup year, 2004, as well as those that survived over the period (2004-2008). As shown in Table I, there were 80 women-owned technology-based startups in 2004 compared with 446 startups established by men. In terms of human capital, women high tech entrepreneurs launched their firms with fewer years of previous industry work experience ( 1 I.8 years vs. 16.5 years) as 
well as less experience in previously starting a business (33.6\% vs $50 \%$ ). Women also worked fewer hours per week on average (38.9 hours vs. 42.8 hours) and were less likely to have completed a graduate degree $(22.7 \%$ vs. $33.4 \%$, although these differences were not statistically significant. Since human capital has been shown to be an important predictor of firm survival and success (Coleman, 2007; Carter et al., 1997; Bosma et al., 2004), the fact that women start their firms with lower levels of many different factors that make up human capital has implications for both firm performance and the ability to attract sources of capital.

In 2008, there were 55 surviving women-owned technology-based firms compared with 305 surviving firms owned by men. Table I reveals that a higher percentage of women-owned firms indicated that the firm's performance met their expectations during the first five years of its existence ( $55.3 \%$ vs. $44.8 \%$ ), but this difference was not statistically significant. Similarly, a higher percentage of women were considered to be optimistic than men ( $40.2 \%$ vs. $33.2 \%)$. In terms of future performance, a significantly lower percentage of women entrepreneurs indicated that they had high growth expectations for their firms over the next few years (21.2\% vs. $40.3 \%$ ). Since a higher percentage of women responded that they were satisfied with the firm's performance after five years while a lower percentage indicated high growth expectations, these findings suggest that women have more modest goals than men in the areas of growth and profits. Alternatively, and consistent with prior research, women may be more highly motivated by lifestyle types of considerations such as flexibility and the ability to be their own boss (Boden, 1999; Buttner and Moore, 1997; Fairlie and Robb, 2009; Orser and Hogarth-Scott, 2002). Table I reveals that a lower percentage of women technology-based entrepreneurs were married than men $(66.1 \%$ vs. $78.1 \%)$. Nevertheless, the percentage of married high tech entrepreneurs is relatively high for both men and women possibly suggesting that support from a spouse can be a key ingredient to entrepreneurial success. Fewer women than men had achieved a wealth level of more than $\$ 250,000$ (37.3\% vs. $49.6 \%$ ), which could affect their ability to leverage larger sums of borrowed capital or capital invested by others. These latter differences were not statistically significant however.
Table I also provides information on the highest degree obtained by both women and men technology-based entrepreneurs. Although women were less likely to have degrees in science $(38.7 \%$ vs. $42.8 \%)$, they were more likely to have degrees in technical (19.3\% vs. $14.8 \%)$ or business fields ( $24.7 \%$ vs. $22.7 \%$ ). None of these differences were statistically significant. Since this sample focuses exclusively on entrepreneurs who started technologybased firms, it is not surprising that such a high percentage of women had degrees in technical fields. It does indicate, however, that women pursuing technology-based entrepreneurship are preparing themselves with the necessary educational background, also a key element of human capital.

Table 2 provides additional comparisons of the characteristics of women- and men-owned technologybased firms in the startup year as well as the most recent year of observation. Women-owned technology-based firms were significantly less likely than men to be organized as corporations $(54.1 \%$ vs. $76.1 \%$ ) and slightly more likely to operate firms out of their home $(59.6 \%$ vs. $52.9 \%)$. Both of these findings suggest that women-owned firms were smaller than firms owned by men and had less complex organizational structures. These could also be considered as related measures of women's lower growth expectations.

In the startup year, women technology-based entrepreneurs were somewhat more likely to say that they had some type of competitive advantage ( $73.1 \%$ vs. $70.6 \%$ ), and they were slightly more likely to have employees ( $41.0 \%$ vs. $39.6 \%)$. This pattern changed fairly dramatically by the fourth follow-up year, however. By 2008, men were more likely to say that their firms had a competitive advantage $(68.6 \%$ vs. $61.5 \%)$, and men-owned firms were dramatically more likely to report that they employed other employees ( $65.1 \%$ vs. $47.0 \%$ ). In fact, by 2008 , less than half of women-owned technology-based firms had employees, compared with almost two-thirds of menowned firms. This difference was statistically significant.

Table 2 indicates that women technology-based entrepreneurs were more likely to have high credit scores in both 2004 and in 2008. The proportion of surviving firms with a female primary owner with high scores increased more than for men over the five year period and became statistically significant in the latter period. This may 
suggest that women are more concerned about protecting the firm and themselves from the risks associated with high levels of debt. Alternatively, it may suggest a preference for debt as a financing source to avoid sharing control with other equity investors. If this is the case, it would be important for the entrepreneur to maintain a high credit score in order to secure debt capital and to secure it on favorable terms.

\begin{tabular}{|c|c|c|c|c|}
\hline \multicolumn{4}{|c|}{ Table One } & \\
\hline \multicolumn{4}{|c|}{ Primary Owner Characteristics of Technology Based Firms } & \\
\hline & & \multicolumn{2}{|c|}{ All: 2004} & \\
\hline & & Female & Male & \\
\hline \multicolumn{2}{|c|}{ Owner Age } & 44.9 & 44.8 & \\
\hline \multicolumn{2}{|c|}{ Years of Previous Industry Work Experience } & 11.8 & 16.5 & $* * *$ \\
\hline \multicolumn{2}{|c|}{ Previous Startup Experience } & $36.3 \%$ & $50.0 \%$ & $*$ \\
\hline \multicolumn{2}{|c|}{ Number of Previous Startups } & 0.649 & 1.281 & $* *$ \\
\hline \multicolumn{2}{|c|}{ Average Hours Worked (week) } & 38.9 & 42.8 & \\
\hline \multicolumn{5}{|c|}{ Education Level } \\
\hline & High School Graduate or less & $3.2 \%$ & $3.6 \%$ & \\
\hline & Some College & $28.7 \%$ & $26.8 \%$ & \\
\hline & College Degree & $45.4 \%$ & $36.2 \%$ & \\
\hline & Post-Grad Education & $22.7 \%$ & $33.4 \%$ & \\
\hline \multirow[t]{3}{*}{$\mathrm{N}$} & & 80 & 446 & \\
\hline & & \multicolumn{2}{|c|}{ Surviving Firms: 2008} & \\
\hline & & Female & Male & \\
\hline \multicolumn{2}{|c|}{ Met or Exceeded Expectations for first four years } & $55.3 \%$ & $44.8 \%$ & \\
\hline \multicolumn{2}{|c|}{ High Growth Expectations (30+\%) } & $21.2 \%$ & $40.3 \%$ & $* * *$ \\
\hline \multicolumn{2}{|c|}{ High Wealth (250K) } & $37.3 \%$ & $49.6 \%$ & \\
\hline \multicolumn{2}{|c|}{ Married } & $66.1 \%$ & $78.1 \%$ & \\
\hline \multicolumn{2}{|c|}{ Optimist } & $40.2 \%$ & $33.2 \%$ & \\
\hline \multicolumn{5}{|c|}{ Focus of Highest Degree } \\
\hline & Science & $38.7 \%$ & $42.8 \%$ & \\
\hline & Technical & $19.3 \%$ & $14.8 \%$ & \\
\hline & Business & $24.7 \%$ & $22.7 \%$ & \\
\hline & Liberal Arts & $11.7 \%$ & $18.4 \%$ & \\
\hline & Other & $5.6 \%$ & $1.2 \%$ & \\
\hline $\mathrm{N}$ & & 55 & 305 & \\
\hline \multicolumn{2}{|c|}{$* * * p<0.01, * * p<0.05, * p<0.1$} & & & \\
\hline \multicolumn{4}{|c|}{$\begin{array}{l}\text { Source: Kauffman Firm Survey Microdata. Sample includes only surviving } \\
\text { firms over the period } 2004-2008 \text { and those that have been verified as going } \\
\text { out of business over the same period. }\end{array}$} & \\
\hline
\end{tabular}


Table 2

\begin{tabular}{|c|c|c|c|c|c|c|}
\hline \multicolumn{6}{|c|}{ Table 2} & \\
\hline \multicolumn{6}{|c|}{ Firm Characteristics of Technology Based Firms by Gender } & \\
\hline & \multicolumn{2}{|c|}{ All Firms: 2004} & & \multicolumn{2}{|c|}{ Surviving Firms: 2008} & \\
\hline & Female & Male & & Female & Male & \\
\hline Incorporated & $54.1 \%$ & $76.1 \%$ & $* * *$ & $65.6 \%$ & $79.5 \%$ & \\
\hline Home Based & $59.6 \%$ & $52.9 \%$ & & $53.9 \%$ & $46.1 \%$ & \\
\hline Comparative Advantage & $73.1 \%$ & $70.6 \%$ & & $61.5 \%$ & $68.6 \%$ & \\
\hline Employer Firm & $41.0 \%$ & $39.6 \%$ & & $47.0 \%$ & $65.1 \%$ & $* *$ \\
\hline High Credit Score & $18.5 \%$ & $13.2 \%$ & & $29.1 \%$ & $17.1 \%$ & $*$ \\
\hline Medium Credit Score & $61.4 \%$ & $61.7 \%$ & & $62.2 \%$ & $72.1 \%$ & \\
\hline Low Credit Score & $20.1 \%$ & $25.1 \%$ & & $8.7 \%$ & $10.9 \%$ & \\
\hline Have Intellectual Property & $25.5 \%$ & $34.5 \%$ & & $28.2 \%$ & $36.1 \%$ & \\
\hline Have Patents & $2.9 \%$ & $6.7 \%$ & $* *$ & $8.2 \%$ & $9.4 \%$ & \\
\hline Have Copyrights & $12.7 \%$ & $18.7 \%$ & & $15.1 \%$ & $20.5 \%$ & \\
\hline Have Trademarks & $15.8 \%$ & $23.4 \%$ & & $13.8 \%$ & $24.2 \%$ & $* *$ \\
\hline Ave. \# Patents & 5.3 & 4.4 & & 3.1 & 5.3 & \\
\hline Ave. \# Copyrights & 7.1 & 7.3 & & 25.0 & 11.7 & \\
\hline Ave. \# Trademarks & 2.6 & 2.0 & & 2.2 & 2.4 & \\
\hline Average Revenues & $\$ 83,568$ & $\$ 116,164$ & & $\$ 346,042$ & $\$ 635,378$ & $* *$ \\
\hline Average Assets & $\$ 49,742$ & $\$ 71,879$ & & $\$ 90,548$ & $\$ 162,245$ & $* * *$ \\
\hline Average Employment & 1.2 & 2.1 & & 2.6 & 5.1 & $* *$ \\
\hline$* * * \mathrm{p}<0.01, * * \mathrm{p}<0.05, * \mathrm{p}<0$. & & & & & & \\
\hline \multicolumn{6}{|c|}{$\begin{array}{l}\text { Source: Kauffman Firm Survey Microdata. Sample includes only surviving firms } \\
\text { over the period } 2004-2008 \text { and those that have been verified as going out of } \\
\text { business over the same period. }\end{array}$} & \\
\hline
\end{tabular}

In terms of intellectual property, a higher percentage of men technology-based entrepreneurs had some type of intellectual property in both 2004 and 2008. This was true for various types of intellectual property including patents, copyrights, and trademarks. The difference was only statistically significant for having patents in 2004 and having trademarks in 2008. Since intellectual property protection can serve as a barrier to entry, it is an important form of competitive advantage that can increase a firm's prospects for survival, growth, and revenues. In spite of this distinction, however, Table 2 reveals that, for those firms that actually had some type of intellectual property, women had roughly the same average number of patents, trademarks, and copyrights in the startup year. By the fifth year of operation, however, women-owned firms lagged in average number of patents, although they had a much higher average number of copyrights.
Finally, Table 2 reveals that women-owned technologybased firms were dramatically smaller than men-owned firms in terms of average revenues, assets, and employment. While this was true in the startup year, it also appears that the gap between women and men in these performance measures actually widened over the ensuing years for firms that survived over the period. In 2008 all of these differences were statistically significant.

\section{B. Sources of Financial Capital}

Table 3 provides information on the financing sources and amounts for women- and men-owned firms at startup (2004) and over the course of the next four years (20052008). It reveals that women raised significantly smaller amounts of capital at startup and relied more heavily on internal rather than external sources of financing. In 2004, women raised an average of $\$ 65,187$ to start their firms, 
compared with $\$ 156,486$ for men. The fact that women raised only 42 percent of the amount that men raised to start their firms has implications for their ability to introduce new products and services, expand geographically, hire additional employees, and survive.

Firms can finance their ventures through debt or equity. Owners can self-finance (owner finance) their ventures or rely on others. In terms of others, owners can rely on "insiders" (friends, family, etc.), or rely on "outsiders" (formal bank debt, business credit cards, venture capital, angel investments, etc.). Insider financing and outsider financing are sometimes also referred to as informal and formal financing. Our categorization of the different financing sources follows Robb and Robinson (2009). For a detailed breakout of the elements that make up each of the six broad financing categories listed in Table 3, please see Appendix B.

Table 3

Capital Structure of New Technology-Based Firms

Initial Start Up Capital \& New Financial Injections

\begin{tabular}{|c|c|c|c|c|c|c|c|}
\hline \multirow[b]{2}{*}{ Start Up Capital } & \multicolumn{7}{|c|}{ All Firms: 2004} \\
\hline & \multicolumn{2}{|c|}{ Female } & \multicolumn{2}{|r|}{ Male } & & \multirow{2}{*}{$\begin{array}{c}\text { Female } \\
32.2 \%\end{array}$} & \multirow{2}{*}{$\begin{array}{l}\text { Male } \\
20.4 \%\end{array}$} \\
\hline Owner Equity & $\$$ & 20,967 & $\$$ & 31,857 & & & \\
\hline Insider Equity & $\$$ & 1,993 & $\$$ & 2,482 & & $3.1 \%$ & $1.6 \%$ \\
\hline Outsider Equity & $\$$ & 2,654 & $\$$ & 74,004 & $* *$ & $4.1 \%$ & $47.3 \%$ \\
\hline Owner Debt & $\$$ & 5,558 & $\$$ & 6,871 & & $8.5 \%$ & $4.4 \%$ \\
\hline Insider Debt & $\$$ & 2,699 & $\$$ & 4,292 & & $4.1 \%$ & $2.7 \%$ \\
\hline Outsider Debt & $\$$ & 31,317 & $\$$ & 36,981 & & $48.0 \%$ & $23.6 \%$ \\
\hline \multirow[t]{3}{*}{ Total Financial } & $\$$ & 65,187 & $\$$ & 156,486 & $* *$ & $100.0 \%$ & $100.0 \%$ \\
\hline & \multicolumn{7}{|c|}{ Average Annual New Injections (2005-2008) } \\
\hline & \multicolumn{2}{|c|}{ Female } & \multicolumn{2}{|r|}{ Male } & & Female & Male \\
\hline Owner Equity & $\$$ & 6,768 & $\$$ & 33,896 & $* *$ & $11.3 \%$ & $19.8 \%$ \\
\hline Insider Equity & $\$$ & 545 & $\$$ & 3,996 & & $0.9 \%$ & $2.3 \%$ \\
\hline Outsider Equity & $\$$ & 16,999 & $\$$ & 77,893 & & $28.4 \%$ & $45.5 \%$ \\
\hline Owner Debt & $\$$ & 7,396 & $\$$ & 5,581 & & $12.4 \%$ & $3.3 \%$ \\
\hline Insider Debt & $\$$ & 2,624 & $\$$ & 6,088 & & $4.4 \%$ & $3.6 \%$ \\
\hline Outsider Debt & $\$$ & 25,477 & $\$$ & 43,872 & $* *$ & $42.6 \%$ & $25.6 \%$ \\
\hline Total Financial & $\$$ & 59,809 & $\$$ & 171,326 & $* *$ & $100.0 \%$ & $100.0 \%$ \\
\hline \multicolumn{3}{|c|}{$* * * p<0.01, * * p<0.05, * p<0.1$} & & & & & \\
\hline
\end{tabular}

Source: Kauffman Firm Survey Microdata. Sample includes only surviving firms over the period 2004-2008 and those that have been verified as going out of business over the same period.

For women-owned firms, the major sources of financing at startup were owner or personal equity (32.2\%) and outsider debt (48.0\%). Women used negligible amounts of equity provided by either insiders or outsiders. In contrast, men-owned firms were less reliant on both owner equity $(20.4 \%)$ and outsider debt $(23.6 \%)$ than women, while almost half of their startup financing (47.3\%) was provided by outside equity. Men's greater reliance on outside equity to fund their firms may suggest that they were more open to sharing ownership and control with outsiders. Alternatively, it may suggest that men have greater access to networks that provide links to investors willing to supply equity capital. Whatever the reason, these findings reveal marked differences in financing strategy between women- and men-owned technology-based firms during the startup year.

Table 3 also demonstrates that the financing differences between women and men persisted over the course of the next four years. From 2005 to 2008, women injected 
an average of $\$ 60,000$ in new financial capital, compared with more than $\$ 170,000$ for men. Interestingly, men were more reliant on owner equity during this timeframe (19.8\% vs. II.3\%). This could be a function of their higher earnings due the higher average firm growth and revenues as shown on Table 2. Thus, men may have had the opportunity to accumulate larger amounts of personal wealth that could be invested in the business. In the follow-on years of 2005-2008, women continued to be more reliant on outsider debt $(42.6 \%$ vs. $25.6 \%)$ and less reliant on outsider equity $(28.4 \%$ vs. $45.5 \%)$ than men. This contrast suggests that women were either reluctant to relinquish control to other equity holders, or alternatively, that they did not have access to key networks that could put them in touch with equity investors.

\subsection{Results of Multivariate Analysis}

Does gender play a role in determining initial capital structure patterns of new technology-based firms? Table 4 suggests that this is indeed the case. When we regressed various capital structure ratios against owner and firm characteristics as described in Section 2.2, we found that women used significantly higher ratios of outside debt to total capital and significantly lower ratios of outside equity to total capital than men to launch their firms. In fact, Table 4 reveals that, on average, new technology-based firms owned by women relied more heavily on outside debt and less heavily on outside equity, compared with those owned by men. Our results also indicated that women also used lower ratios of owner financincing and insider financing, although those differences were not statistically significant.

Our results do not allow us to conclude that women were discriminated against in their pursuit of external equity, but other significant variables shed light on our findings. Specifically, owners having a graduate degree, and firms having some type of intellectual property used significantly higher ratios of outsider equity to total financial capital. These findings confirm our hypothesis that, in the presence of asymmetric information, measures of human capital such as education and the competitive advantage provided by intellectual property can serve as positive signals to potential equity investors. Our univariate analysis indicated that a) women were less likely than men to have graduate degrees, and b) women- owned firms were less likely than men to have intellectual property. Further, external equity providers typically derive their returns from growth and capital gains. Our univariate results also revealed that women-owned firms had lower growth aspirations than firms owned by men. Taken together, these findings suggest that, on average, women-owned new technology-based firms are less likely to have characteristics that appeal to external providers of equity. The results provided in Table 4 reveal, however, that, even controlling for human capital and the presence of intellectual property, women-owned firms still used lower levels of outside equity. This finding suggests that factors other than the preferences of external equity providers are at work.

Conversely, women-owned firms used a significantly higher ratio of external debt to total capital. If women use less external equity, they may turn to external debt as a substitute. The advantage of external debt from the entrepreneur's perspective is that it allows her to control the growth of the firm, and it does not necessitate sharing ownership or control with outsiders. Some prior research has suggested that women entrepreneurs prefer moderate to rapid growth and are reluctant to share control (Cliff, 1998; Morris et al., 2006; Orser and Hogarth-Scott, 2002).

Other significant variables in the model using outsider debt/total financial capital as the dependent variable included hours worked and having a high credit score. In contrast, the variables representing multiple owners and intellectual property were significant and negative. These findings suggest that owners who have higher levels of debt substitute their own human capital for the financial capital that could be provided by multiple owners or external equity investors. This allows them to maintain ownership and control. As we hypothesized, firms that are highly reliant on debt need to maintain a high credit score in order to secure access and credit at a reasonable price. Finally, although intellectual property may act as a positive signal to equity investors, it is less appealing to debt investors who prefer physical assets and property that can be used as collateral on loans. Thus, high credit scores act as a positive signal to providers of debt, while having intellectual property in the form of patents, copyrights, and trademarks acts as a positive signal to providers of equity. Our results indicate, however, that, even controlling for credit 
quality and intellectual property, women-owned technology startups relied more heavily on external debt while men-owned technology startups relied more heavily on external equity. This dichotomy strongly suggests differences in the funding preferences and strategies of women- and men-owned firms that a similar in other respects.

Table 4

Start Up Capital Financing Ratios for Technology-Based Firms

\begin{tabular}{|c|c|c|c|c|}
\hline & Owner Financing/ & Insider Financing/ & Outsider Debt/ & Outsider Equity/ \\
\hline VARIABLES & Total FK & Total FK & Total FK & Total FK \\
\hline \multirow[t]{2}{*}{ Female Primary Owner } & -0.0604 & -0.0145 & $0.115^{* *}$ & $-0.0401^{* *}$ \\
\hline & $(0.0558)$ & $(0.0164)$ & $(0.0501)$ & $(0.0203)$ \\
\hline \multirow[t]{2}{*}{ Hours Worked (week) } & $-0.00191^{* *}$ & $0.00112^{* * *}$ & $0.00132 * *$ & -0.000531 \\
\hline & $(0.000767)$ & $(0.000327)$ & $(0.000571)$ & $(0.000365)$ \\
\hline \multirow[t]{2}{*}{ Some College } & 0.000254 & -0.00983 & -0.0180 & 0.0276 \\
\hline & $(0.103)$ & $(0.0296)$ & $(0.0909)$ & $(0.0319)$ \\
\hline \multirow[t]{2}{*}{ College Degree } & 0.0796 & -0.0231 & -0.104 & 0.0477 \\
\hline & $(0.100)$ & $(0.0288)$ & $(0.0864)$ & $(0.0342)$ \\
\hline \multirow[t]{2}{*}{ Graduate Degree } & 0.0479 & -0.0396 & -0.0858 & $0.0775^{*}$ \\
\hline & $(0.103)$ & $(0.0283)$ & $(0.0857)$ & $(0.0420)$ \\
\hline \multirow[t]{2}{*}{ Prev. Industry Exp. (years) } & 0.00140 & -0.00113 & 0.00103 & -0.00130 \\
\hline & $(0.00183)$ & $(0.000696)$ & $(0.00127)$ & $(0.00116)$ \\
\hline \multirow[t]{2}{*}{ Prev. Start Up Exp. } & 0.0575 & $-0.0368 * *$ & -0.0318 & 0.0111 \\
\hline & $(0.0360)$ & $(0.0155)$ & $(0.0301)$ & $(0.0178)$ \\
\hline \multirow[t]{2}{*}{ Home Based } & -0.0128 & -0.00847 & 0.0185 & 0.00277 \\
\hline & $(0.0380)$ & $(0.0170)$ & $(0.0296)$ & $(0.0206)$ \\
\hline \multirow[t]{2}{*}{ Multi-Owner Firm } & $0.130 * * *$ & -0.0168 & $-0.0685^{* *}$ & $-0.0451^{* * *}$ \\
\hline & $(0.0375)$ & $(0.0161)$ & $(0.0315)$ & $(0.0170)$ \\
\hline \multirow[t]{2}{*}{ Intellectual Property } & 0.0124 & -0.0290 & $-0.0702^{* *}$ & $0.0868^{*}$ \\
\hline & $(0.0657)$ & $(0.0187)$ & $(0.0292)$ & $(0.0493)$ \\
\hline \multirow[t]{2}{*}{ High Credit Score } & -0.00358 & 0.0117 & $0.0777^{* *}$ & $-0.0858^{*}$ \\
\hline & $(0.0689)$ & $(0.0172)$ & $(0.0313)$ & $(0.0513)$ \\
\hline \multirow[t]{2}{*}{ Medium Credit Score } & -0.0360 & $0.0453^{* *}$ & -0.0306 & 0.0212 \\
\hline & $(0.0397)$ & (0.0199) & $(0.0311)$ & $(0.0197)$ \\
\hline \multirow[t]{2}{*}{ Firm Offers Product } & -0.0484 & -0.0231 & 0.0327 & $0.0388^{*}$ \\
\hline & $(0.0566)$ & $(0.0234)$ & $(0.0504)$ & $(0.0232)$ \\
\hline \multirow[t]{2}{*}{ Firm Offers Products \& Services } & -0.0441 & 0.000775 & 0.00228 & $0.0410^{* * *}$ \\
\hline & $(0.0396)$ & $(0.0189)$ & $(0.0350)$ & $(0.0140)$ \\
\hline \multirow[t]{2}{*}{ Constant } & $0.741^{* * *}$ & $0.0722^{*}$ & $0.178 *$ & 0.00920 \\
\hline & (0.109) & $(0.0395)$ & $(0.0915)$ & $(0.0462)$ \\
\hline Observations & 468 & 468 & 468 & 468 \\
\hline R-squared & 0.110 & 0.088 & 0.101 & 0.099 \\
\hline \multicolumn{5}{|l|}{ Standard errors in parentheses } \\
\hline \multicolumn{5}{|l|}{$* * * p<0.01, * * p<0.05, * p<0.1$} \\
\hline \multicolumn{5}{|c|}{ Excluded categories are male, less than some college, low credit score, firm offers service(s) } \\
\hline \multicolumn{3}{|c|}{ Source: Kauffman Firm Survey Microdata. Technology-based firms only. } & & \\
\hline
\end{tabular}

ISSN: 07I 8-2724. (http://www.jotmi.org)

Journal of Technology Management \& Innovation ( ) Universidad Alberto Hurtado, Facultad de Economía y Negocios 
Gender was not a significant variable in the model in which owner financing/total financial capital was the dependent variable or in the model in which insider financing/total financial capital was the dependent variable. These findings indicate that there were no significant differences between women- and men-owned new technology-based firms in terms of the level of personal financing used or the level of financing provided by other insiders.

How do these financing strategies affect firm outcomes? As an additional step we examined only those firms that survived over the full period 2004-2008 to determine I) if gender was related to firm outcomes, 2) whether firm outcomes met the expectations that owners had at startup, and 3) the extent to which variables representing firm and owner characteristics (including gender) affected expectations for the firm. We ran probit regressions on the following dependent binary dependent variables: I) firm achieved revenues of more than $100 \mathrm{~K}$ by 2008,2 ) firm had assets of more than $100 \mathrm{~K}$ by 2008 , 3) firm employed individuals other than the firm owner by 2008 , 4) firm met or exceeded expectations held by the owner at startup, and 5) owner expectations for the future include growth of 30 percent or more over the 2008$201 \mathrm{I}$ period. Probit analysis is appropriate in instances where the variable is dichotomous and the researcher is attempting to determine the probability of one outcome relative to the other.

In addition to the control variables from the previous regressions, we added the ratio of outside debt to total financial capital and whether or not the firm had employees in the startup year as additional independent variables. The ratio of outside debt to total financial capital is an indication of the extent to which the firm relies on external debt rather than external equity as a source of capital. The presence of employees at startup is another measure of growth expectations and intentions. Entrepreneurs would only add employees in the early stages of the firm if they expected revenues to achieve a level that would justify their presence. The results of our analysis are provided in Table 5.
Table 5 reveals that, by the fifth year of the firm's operation, women-owned new technology-based firms were significantly less likely to have assets in excess of $\$ 100 \mathrm{~K}$ and significantly less likely to have employees than men-owned new technology-based firms. While womenowned firms were also less likely to have revenues in excess of $\$ 100 \mathrm{~K}$, the difference was not statistically significant. Our results indicate that women were about as likely as men to say that their firm performance during the early years met or exceeded their expectationsthere was no statistically significant effect of gender. Nevertheless, women-owned firms were significantly less likely than men to have high growth expectations for the future. This set of results provides us with some interesting new insights into the motivations and goals of women-owned new technology-based firms. Although women launched smaller and less growth-oriented firms than those owned by men, they were, on average, happy with the firm's performance during its first five years. These findings strongly suggest that women-owned firms are motivated by factors other than firm size and rapid growth

Table 5 also reveals that, in general, high performing firms were associated with owners who worked longer hours and had previous startup experience, firms that had multiple owners and employees, and firms that had medium to high credit scores. Conversely, home-based firms were significantly less likely to have high revenues or employees. In particular, high growth expectations were positively associated with previous startup experience, intellectual property, a medium credit score, and being male, while they were negatively associated with a higher ratio of outside debt/total financial capital and being female. These findings would seem to suggest that the owners of growth-oriented firms make a commitment to raising external equity. In other words, they understand and accept the fact that they will have to share ownership with other equity providers to achieve their growth expectations. 
Table 5

Outcomes for Surviving Firms in 2008

\begin{tabular}{|c|c|c|c|c|c|}
\hline & & & & Met or & \\
\hline & Revenue > & Assets > & Employer & Exceeded & High Growth \\
\hline VARIABLES & $\$ 100 K$ & $\$ 100 K$ & Firm & Expectations & 5 Expectations \\
\hline \multirow[t]{2}{*}{ Female Primary Owner } & -0.0718 & $-0.203 * *$ & $-0.271 * * *$ & 0.0592 & $-0.146^{*}$ \\
\hline & $(0.118)$ & $(0.0938)$ & $(0.101)$ & $(0.100)$ & $(0.0887)$ \\
\hline \multirow[t]{2}{*}{ Hours Worked (week) } & $0.00487^{* * *}$ & $0.00279 *$ & 0.000815 & 0.000327 & 0.00110 \\
\hline & $(0.00161)$ & $(0.00164)$ & $(0.00157)$ & $(0.00156)$ & $(0.00156)$ \\
\hline \multirow[t]{2}{*}{ Some College } & -0.237 & -0.0483 & -0.146 & 0.00404 & -0.225 \\
\hline & $(0.186)$ & $(0.205)$ & $(0.179)$ & $(0.203)$ & $(0.155)$ \\
\hline \multirow[t]{2}{*}{ College Degree } & -0.252 & 0.0187 & -0.214 & -0.0883 & -0.113 \\
\hline & $(0.187)$ & (0.198) & $(0.173)$ & $(0.203)$ & $(0.174)$ \\
\hline \multirow[t]{2}{*}{ Graduate Degree } & -0.197 & 0.00541 & -0.162 & 0.0344 & -0.0564 \\
\hline & $(0.188)$ & $(0.198)$ & $(0.174)$ & $(0.206)$ & $(0.177)$ \\
\hline \multirow[t]{2}{*}{ Prev. Industry Exp. (years) } & -0.00530 & $-0.00730 *$ & 0.000808 & -0.00447 & -0.000342 \\
\hline & $(0.00369)$ & $(0.00379)$ & $(0.00360)$ & $(0.00347)$ & $(0.00436)$ \\
\hline \multirow[t]{2}{*}{ Prev. Start Up Exp. } & 0.105 & $0.184^{* *}$ & -0.0933 & 0.0512 & $0.149 * *$ \\
\hline & $(0.0735)$ & $(0.0722)$ & $(0.0704)$ & $(0.0719)$ & $(0.0681)$ \\
\hline \multirow[t]{2}{*}{ Multi-Owner Firm } & $0.273^{* * *}$ & $0.229 * * *$ & $0.180 * *$ & -0.0919 & -0.0517 \\
\hline & $(0.0780)$ & $(0.0793)$ & $(0.0746)$ & $(0.0818)$ & $(0.0815)$ \\
\hline \multirow[t]{2}{*}{ Home Based } & $-0.231 * * *$ & -0.125 & $-0.187^{* *}$ & 0.00517 & -0.101 \\
\hline & $(0.0764)$ & $(0.0823)$ & $(0.0736)$ & $(0.0819)$ & $(0.0773)$ \\
\hline \multirow[t]{2}{*}{ Firm Offers Product } & -0.0958 & 0.0981 & 0.0607 & 0.0205 & -0.0600 \\
\hline & $(0.117)$ & (0.134) & $(0.134)$ & $(0.125)$ & $(0.122)$ \\
\hline \multirow[t]{2}{*}{ Firm Offers Products \& Services } & 0.110 & -0.184 & 0.0223 & -0.0394 & 0.0974 \\
\hline & $(0.113)$ & $(0.130)$ & $(0.127)$ & $(0.126)$ & $(0.120)$ \\
\hline \multirow[t]{2}{*}{ Intellectual Property } & -0.0568 & 0.115 & 0.0624 & -0.0821 & $0.176^{* *}$ \\
\hline & $(0.0787)$ & $(0.0784)$ & $(0.0768)$ & $(0.0802)$ & $(0.0781)$ \\
\hline \multirow[t]{2}{*}{ High Credit Score } & 0.200 & $0.394^{* * *}$ & 0.143 & $0.211^{*}$ & 0.120 \\
\hline & $(0.122)$ & $(0.110)$ & $(0.105)$ & $(0.110)$ & $(0.128)$ \\
\hline \multirow[t]{2}{*}{ Medium Credit Score } & 0.0924 & $0.219 * *$ & -0.0273 & 0.0515 & $0.161^{*}$ \\
\hline & $(0.0911)$ & $(0.0883)$ & $(0.0886)$ & $(0.0900)$ & $(0.0942)$ \\
\hline \multirow[t]{2}{*}{ Outside Debt/Total FK } & 0.0390 & $0.298^{* *}$ & -0.00895 & 0.0156 & $-0.231^{*}$ \\
\hline & $(0.144)$ & $(0.130)$ & $(0.133)$ & $(0.130)$ & $(0.128)$ \\
\hline \multirow[t]{2}{*}{ Employer firm in 2004} & $0.248^{* * *}$ & $0.158^{*}$ & $0.312^{* * *}$ & -0.0515 & 0.0371 \\
\hline & $(0.0783)$ & $(0.0844)$ & $(0.0665)$ & $(0.0798)$ & $(0.0770)$ \\
\hline Observations & 316 & 316 & 316 & 316 & 314 \\
\hline
\end{tabular}

Standard errors in parentheses

*** $\mathrm{p}<0.01, * * \mathrm{p}<0.05,{ }^{*} \mathrm{p}<0.1$

Excluded categories are male, less than some college, low credit score, firm offers service(s)

Source: Kauffman Firm Survey Microdata. Technology-based firms only. 


\subsection{Summary of Findings}

A review of the descriptive statistics provided in Tables I3 reveals striking differences between women- and menowned new technology-based firms in terms of owner and firm characteristics and financing strategies. Women owners had different human capital attributes than men owners in the areas of education and prior experience. Further, women-owned firms were more likely to be organized as sole proprietorships and were more likely to be home-based. Finally, women-owned firms were less likely to have some type of intellectual property in the form or patents, copyrights, or trademarks. In terms of performance, women-owned new technology-based firms were smaller than men-owned firms at startup and in their fifth year of operation in measures of revenues, assets, and employees.

Some of the performance differences between womenand men-owned new technology-based firms can be explained by differences in financing strategy. Women started their firms with smaller amounts financial capital, and they relied more heavily on external sources of debt and less heavily on external sources of equity than men. As noted above, women may have preferred to use external debt rather than external equity because they did not want to share ownership and control. Alternatively, as suggested by prior research, they may have been closed out of external sources of equity financing, because they lacked access to key funding networks (Brush et al., 200I; Gatewood et al., 2009).

Our findings suggest that the motivations and expectations of the entrepreneur have an important role in financing strategy. Specifically, women entrepreneurs in our study had lower expectations for growth than men. Further, although their levels of revenues, assets, and employment were lower than those of men-owned firms, women owners were more likely than men to state that the firm's performance met or exceeded their expectations during its first five years. These findings suggest that women who established new technology-based firms did not necessarily measure success using the traditional economic measures of firm size and growth. Alternatively, it appears that women may be driven more by goals such as "being my own boss" or "doing something I love". If this is the case, their preference for external debt which allows them to maintain control rather than external equity which would require them to share or relinquish control may be a conscious choice rather than a funding necessity.

\section{Conclusions}

In this article we have examined the financing strategies of new technology-based firms. In particular, we have explored differences in the owner and firm characteristics, performance outcomes, and financing strategies of womenand men-owned firms. Our findings have revealed profound differences in all three areas. Consistent with prior research on women-owned firms (Rosa et al., 1996; Du Rietz and Henrekson, 2000; Sabarwal and Terrell, 2009; Fairlie and Robb, 2009), new women-owned firms in technology fields were smaller and less growth-oriented than men-owned firms. Further, women and men owners of technology-based firms displayed differences in both education and experience, also consistent with prior research (Carter et al., 2003; Menzies et al., 2004). These differences in owner and firm characteristics have the potential to affect both the demand and the supply side of the financial capital equation. Firms that are less growthoriented may choose to rely more heavily on internal sources of capital and external debt. Conversely, firms that are not growth-oriented, and firm owners who do not have the "right" kind of education and experience may be less attractive to equity investors (Greene et al., 200I; Menzies et al., 2004).

One of the most important contributions of this article is that it builds upon the small but important body of work establishing a link between owner motivations and expectations, financing strategy, and firm performance (Cliff, 1998; Morris et al., 2006; Orser and Hogarth-Scott, 2002). Previous studies have tended to gauge the success of firms based on the traditional economic measures of size, growth, and profits. In contrast, our article reveals that the women owners of new technology-based firms were less likely to have high expectations for either growth or personal wealth. Nevertheless, they were more likely than men to be satisfied with the firm's performance and to be optimistic about its future. Clearly, economic measures of success were not the only or even necessarily the most important measures for this group of women entrepreneurs. These findings are also significant, because all of the entrepreneurs in this study were technologybased entrepreneurs. Thus, we cannot dismiss differences 
in motivation by stating that they are simply a function of industry choice.

A second important contribution of this article is that it clearly demonstrates that women and men owners of new technology-based firms used different financing strategies, either through necessity or choice. Our findings reveal that women raised significantly lower levels of capital to start their firms as well as less capital in subsequent years. Further, women were significantly more reliant on external debt as a source of capital, while men were significantly more reliant on external equity, even controlling for a number of other firm and owner characteristics. Our results do not allow us to rule out the possibility that women are discriminated against or that they may be closed out of key networks that could provide access to external sources of capital. Nevertheless, our findings do suggest that women have different motivations and expectations for their firms, and that those motivations and expectations may lead them to choose some types of capital rather than others. In particular, external equity which is often associated with growth-oriented firms and requires that the entrepreneur share control and ownership may be less appealing to women than it is to men.

A shortcoming of this research is that, although it demonstrates that women are more likely to use external debt and less likely to use external equity, it does not definitively explain why that is the case. The Kauffman data set, although rich in information, does not provide that level of detail. This suggests an opportunity for qualitative research to clarify why women appear to gravitate toward some sources of financing while avoiding others. Do women actually prefer external debt because they do not want to share control, or are they discouraged from applying for it because they do not have the necessary networks and contacts? This is the kind of detail and insight that can be gleaned from qualitative research rather than from survey data ${ }^{3}$. The research findings cited in this article have "pushed the envelope" by expanding upon our understanding of the financing strategies of a growing and important sector of the economy, technology-based firms. Further, this research has laid the groundwork for further

\footnotetext{
${ }^{3}$ However, the next round of the KFS survey includes questions on external equity applications and rejections, which should shed some light on this issue. Those data will be available in March 2011 .
}

discussion and analysis of both women- and men-owned firms in this key sector.

\section{References}

AUDRETSCH, D. B. (2002). The Dynamic Role of Small Firms: Evidence from the U.S. Small Business Economics, I8, I3-40.

AUDRETSCH, D. B., Lehmann, E. E. (2004). Financing High-Tech Growth: The Role of Banks and Venture Capitalists. Schmalenbach Business Review, 56(4), 340-357.

BODEN, R.J. Jr. (1999). Flexible Working Hours, Family Responsibilities, and Female Self-Employment: Gender Differences in Self-Employment Selection. The American Journal of Economics and Sociology, 58(I), 7I-83.

BOLLINGTOFT, A., Parm Ulhoi J., Madsen H., Neergaard H. (2003). The Effect of Financial Factors on the Performance of New Venture Companies in High-Tech and Knowledge-Intensive Industries: An Empirical Study in Denmark. International Journal of Management, 20(4), 535547.

BOSMA, N., Van Praag, M., Thurik, R. (2004). The Value of Human and Social Capital Investments for the Business Peformance of Startups. Small Business Economics, 23(3), 227-236.

BOZKAYA, A., Van Pottelsberghe De La Potterie, B. (2008). Who Funds Technology-based Small Firms? Evidence from Belgium. Economics of Innovation and New Technology, I7(I/2), 97-122.

BRIERLEY, P. (200I). The Financing of Technology-based Small Firms. A Review of the Literature. Bank of England Quarterly Bulletin, 4I(I), 64-76.

BRUSH, C., Carter N., Gatewood E., Greene P., Hart M. (200I). The Diana Project: Women Business Owners and Equity Capital: The Myths Dispelled. Kauffman Foundation, Kansas City, Missouri.

BRUSH, C., Carter, N., Gatewood, E., Greene, P., Hart, M. (200I). The Diana Project: Women Business Owners and Equity Capital: The Myths Dispelled. Kauffman Foundation, Kansas City, Missouri. 
BRUSH, C., Carter, N., Gatewood, E., Greene, P., Hart, M. (2004). Gatekeepers of Venture Growth; A Diana Project Report on the Role and Participation of Women in the Venture Capital Industry. Kauffman Foundation, Kansas City, Missouri.

BUTTNER, E.H., Moore, D.P. (1997). Women's Organizational Exodus to Entrepreneurship: Self Reported Motivations and Correlates with Success. Journal of Small Business Management, 35(I), 34-46.

CARTER, N. M., Williams, M., Reynolds, P.D. (1997). Discontinuance Among New Firms in Retail: The Influence of Initial Resources, Strategy, and Gender. Journal of Business Venturing, 13, 353-369.

CARTER, N.M., Brush, C.G., Greene, P.G., Gatewood, E., Hart, M.M. (2003). Women Entrepreneurs Who Break Through to Equity Financing: The Influence of Human, Social, and Financial Capital. Venture Capital, 5(I), I-28.

CHAPPLE, K., Markusen, A., Schrock, G., Yamamoto, D. (2004). Gauging Metropolitan "High-tech" and "I-tech activity”. Economic Development Quarterly, I8(I), 10-29.

CLIFF, J.E. (1998). Does One Size Fit All? Exploring the Relationship Between Attitudes Toward Growth, Gender, and Business Size. Journal of Business Venturing, 13, 523-542.

COLEMAN, S. (2002). Constraints Faced by Women Small Business Owners: Evidence from the Data. Journal of Developmental Entrepreneurship, 7(2), I5I-I74.

COLEMAN, S. (2007). The Role of Human and Financial Capital in the Profitability and Growth of Women-Owned Small Firms. Journal of Small Business Management, 45(3), 303-319.

COLEMAN, S., Robb, A.M. (2009). Sources of Financing for New Technology Firms: Evidence from the Kauffman Firm Survey. Working paper.

COLOMBO, M. G., Grilli L. (2007). Funding Gaps? Access to Bank Loans by High-Tech Start-Ups. Small Business Economics 29, 25-46.

COOPER, A.C., Gimeno-Gascon, F.J., Woo, C.Y. (1994). Initial Human and Financial Capital as Predictors of New
Venture Performance. Journal of Business Venturing, 9, 37I395.

CROSS, C., Linehan M. (2006). Barriers in Advancing Female Careers in the High-Tech Sector: Empirical Evidence from Ireland. Women in Management Review, $21(1), 28-39$.

DU RIETZ, A., Henrekson M. (2000). Testing the Female Underperformance Hypothesis. Small Business Economics, I4, I-I0.

FAIRLIE, R. W., Robb A. M. (2009). Gender Differences in Business Performance: Evidence from the Characteristics of Business Owners Survey. Small Business Economics, 33, 375-395.

FREEAR, J., Wetzel, Jr., W. E. (1990). Who Bankrolls HighTech Entrepreneurs? Journal of Business Venturing, 5, 77-89.

GATEWOOD, E. J., Brush, C. G., Carter, N. M., Greene, P. G., Hunt, M. M. (2009). Diana: A Symbol of Women Entrepreneurs' Hunt for Knowledge, Money, and the Rewards of Entrepreneurship. Small Business Economics, 32, 129-144.

GREENE, P.G., Brush, C.G., Hart, M.M., Saparito, P. (200I). Patterns of Venture Capital Funding: Is Gender a Factor? Venture Capital, 3(I), 63-83.

GUIDICI, G., Paleari, S. (2000). The Provision of Finance to Innovation: A Survey Conducted Among Italian Technology-based Small Firms. Small Business Economics, I4(I), 37-53.

HOLLOWELL, C., Mellors N., Silver J. (2006). Alternative Routes: A Study on Women and Technology Entrepreneurship in the North-west of England. Entrepreneurship and Innovation, 7(2), II3-I 20.

LERNER, J. (1999). The Government as Venture Capitalist: The Long-Run Impact of the SBIR Program. The Journal of Business, 72(3), 285-318.

MANIGART, S., Struyf C. (1997). Financing HighTechnology Startups in Belgium: An Exploratory Study. Small Business Economics, 9, I25-135. 
MARLOW, S., Patton, D. (2005). All Credit to Men? Entrepreneurship, Finance, and Gender. Entrepreneurship Theory and Practice, 29(3), 526-54I.

MAYER, H. (2008). Segmentation and Segregation Patterns of Women-Owned High-Tech Firms in Four Metropolitan Regions in the United States. Regional Studies, 42(10), I3571383.

MENZIES, T. V., Diochon M., Gasse Y. (2004). Examining Venture-Related Myths Concerning Women Entrepreneurs. Journal of Developmental Entrepreneurship, 9(2), 89-107.

MOORE, B. (1994). Financial Constraints to the Growth and Development of Small High-Technology Firms. In: D.J. Storey and A. Hughes (Eds.) Finance and the Small Firms. Routledge, New York. Pp. I I2-I44.

MORRIS, M.H., Miyasaki, N.N., Watters, C.E., Coombes, S.M. (2006). The Dilemma of Growth: Understanding the Venture Size Choices of Women Entrepreneurs. Journal of Small Business Management, 44(2), 22I-244.

ORSER, B.J., Hogarth-Scott, S., Riding, A.L. (2000). Performance, Firm Size, and Management Problem Solving. Journal of Small Business Management, 38(3), 42-58.

ORSER, B.J., Hogarth-Scott, S. (2002). Opting for Growth: Gender Dimensions of Choosing Enterprise Development. Canadian Journal of Administrative Sciences, 19(3), 284-300.

PAYTAS, J., Berglund, D. (2004, March). Technology Industries and Occupations for NAICS Industry Data. Carnegie Mellon University Center for Economic Development.

ROBB, A. (2002). Entrepreneurial Performance by Women and Minorities: The Case of New Firms. Journal of Developmental Entrepreneurship, 7(4), 383-397.

ROBB, A., Ballou J., DesRoches, D., Potter F., Zhao Z., Reedy E.J. (2009). An Overview of the Kauffman Firm Survey. Kauffman Foundation, Kansas City, Missouri.

ROBB, A., Robinson D. (2009). The Capital Structure Decisions of New Firms. Working Paper.
ROSA, P., Carter S., Hamilton D. (1996). Gender as a Determinant of Small Business Performance: Insights from a British Study. Small Business Economics, 8, 463-478.

SABARWAL, S., Terrell K. (July 2008). Does Gender Matter for Firm Performance? Evidence from the East European and Central Asian Region. IPC Working Paper Series No. 73. http://ssrn.com/abstract $=1223454$. [Accessed 4/I/20I0]

TAl, A. R., Sims, R. L. (2005). The Perception of the Glass Ceiling in High-Technology Companies. Journal of Leadership and Organizational Studies, 12(I), 16-23.

WATSON, J. (2003). Failure Rates for Female-Controlled Businesses: Are They Any Different? Journal of Small Business Management, 4 I (3), 262-277.

WESTHEAD, P., Storey D. J. (1997). Financial Constraints on the Growth of High-Technology Firms in the United Kingdom. Applied Financial Economics, 7, 197-20I. 


\section{Appendix A: NAICS Codes that Make up Technology-Based Category}

\begin{tabular}{|c|c|c|}
\hline NAICS 4 & NAICS 6 & NAICS Industry \\
\hline 2111 & 211100 & Oil and Gas Extraction \\
\hline 2111 & 211111 & Crude Petroleum and Natural Gas Extraction \\
\hline 3251 & 325100 & Basic Chemical Manufacturing \\
\hline 3251 & 325110 & Petrochemical Manufacturing \\
\hline 3251 & 325120 & Industrial Gas Manufacturing \\
\hline 3251 & $325|3|$ & Inorganic Dye and Pigment Manufacturing \\
\hline 3251 & 325182 & Carbon Black Manufacturing \\
\hline 3251 & 325188 & All Other Basic Inorganic Chemical Manufacturing \\
\hline 3251 & 325192 & Cyclic Crude and Intermediate Manufacturing \\
\hline 3251 & 325199 & All Other Basic Organic Chemical Manufacturing \\
\hline 3252 & 325211 & Plastics Material and Resin Manufacturing \\
\hline 3252 & 325212 & Synthetic Rubber Manufacturing \\
\hline 3254 & 325400 & Pharmaceutical and Medicine Manufacturing \\
\hline 3254 & $3254 I I$ & Medicinal and Botanical Manufacturing \\
\hline 3254 & 325412 & Pharmaceutical Preparation Manufacturing \\
\hline 3254 & 325413 & In-Vitro Diagnostic Substance Manufacturing \\
\hline 3254 & 325414 & Biological Product (except Diagnostic) Manufacturing \\
\hline 3332 & 333200 & Industrial Machinery Manufacturing \\
\hline 3332 & 333210 & Sawmill and Woodworking Machinery Manufacturing \\
\hline 3332 & 333220 & Plastics and Rubber Industry Machinery Manufacturing \\
\hline 3332 & 333292 & Textile Machinery Manufacturing \\
\hline 3332 & 333293 & Printing Machinery and Equipment Manufacturing \\
\hline
\end{tabular}




\begin{tabular}{|c|c|c|}
\hline 3332 & 333294 & Food Product Machinery Manufacturing \\
\hline 3332 & 333295 & Semiconductor Machinery Manufacturing \\
\hline 3332 & 333298 & All Other Industrial Machinery Manufacturing \\
\hline 3333 & 333300 & Commercial and Service Industry Machinery Manufacturing \\
\hline 3333 & 333313 & Office Machinery Manufacturing \\
\hline 3333 & 333314 & Optical Instrument and Lens Manufacturing \\
\hline 3333 & 333315 & Photographic and Photocopying Equipment Manufacturing \\
\hline 3333 & 333319 & Other Commercial and Service Industry Machinery Manufacturing \\
\hline 3341 & 334100 & Computer and Peripheral Equipment Manufacturing \\
\hline 3341 & 334111 & Electronic Computer Manufacturing \\
\hline 3341 & 334113 & Computer Terminal Manufacturing \\
\hline 3341 & 334119 & Other Computer Peripheral Equipment Manufacturing \\
\hline 3342 & 334200 & Communications Equipment Manufacturing \\
\hline 3342 & 334210 & Telephone Apparatus Manufacturing \\
\hline & & Radio and Television Broadcasting and Wireless Communications \\
\hline 3342 & 334220 & Equipment Manufacturing \\
\hline 3342 & 334290 & Other Communications Equipment Manufacturing \\
\hline 3343 & 334300 & Audio and Video Equipment Manufacturing \\
\hline 3343 & 334310 & Audio and Video Equipment Manufacturing \\
\hline 3344 & 334400 & Semiconductor and Other Electronic Component Manufacturing \\
\hline 3344 & 334412 & Bare Printed Circuit Board Manufacturing \\
\hline 3344 & 334413 & Semiconductor and Related Device Manufacturing \\
\hline 3344 & $3344 \mid 4$ & Electronic Capacitor Manufacturing \\
\hline 3344 & 334415 & Electronic Resistor Manufacturing \\
\hline 3344 & 334417 & Electronic Connector Manufacturing \\
\hline 3344 & 334418 & Printed Circuit Assembly (Electronic Assembly) Manufacturing \\
\hline
\end{tabular}


$3344 \quad 334419$ Other Electronic Component Manufacturing

$3345 \quad 334500 \quad \begin{aligned} & \text { Navigational, } \\ & \text { Manufacturing }\end{aligned}$

3345334510 Electromedical and Electrotherapeutic Apparatus Manufacturing

Search, Detection, Navigation, Guidance, Aeronautical, and Nautical

$3345 \quad 3345 \mathrm{II} \quad$ System and Instrument Manufacturing

Automatic Environmental Control Manufacturing for Residential,

3345334512 Commercial, and Appliance Use

Instruments and Related Products Manufacturing for Measuring,

33453345 I3 Displaying, and Controlling Industrial Process Variables

$3345 \quad 334514$ Totalizing Fluid Meter and Counting Device Manufacturing

Instrument Manufacturing for Measuring and Testing Electricity and

$3345 \quad 334515 \quad$ Electrical Signals

$3345 \quad 334516 \quad$ Analytical Laboratory Instrument Manufacturing

$3345 \quad 334517 \quad$ Irradiation Apparatus Manufacturing

3345334519 Other Measuring and Controlling Device Manufacturing

5112511200 Software Publishers

$5112 \quad 511210 \quad$ Software Publishers

5413 541300 Architectural, Engineering, and Related Services

$5413 \quad 541310$ Architectural Services

$5413 \quad 541330$ Engineering Services

5413541370 Surveying and Mapping (except Geophysical) Services

$5413 \quad 541380$ Testing Laboratories 


\title{
Appendix B: Financial Structure Categories
}

\author{
Owner Equity \\ Insider Equity \\ Spouse Equity \\ Parent Equity \\ Outsider Equity \\ Other Informal Investors \\ Other Business Equity \\ Government Equity \\ Venture Capital Equity \\ Other Equity
}

\author{
Owner Debt \\ Personal Credit Card -Owner \\ Personal Credit Card-Other Owners \\ Other Personal Owner Loan \\ Insider Debt \\ Personal Family Loan \\ Personal Family Loan-Other Owners \\ Business Loan from family \\ Business Loan from Owner \\ Business Loan from Employee(s) \\ Other Personal Loan
}


Other Personal Funding

Outsider Debt

Personal Bank Loan

Business Credit Card

Other Bank Loan

Business Credit Card-other owners

Business Credit Cards

Bank Business Loan

Credit Line

Other Non-Bank Loan

Government Business Loan

Other Business Loan

Other Individual Loan

Other Business Debt 